\title{
Rediscovery of Nycticebus coucang insularis Robinson, 1917 (Primates: Lorisidae) at Tioman Island and its Mitochondrial Genetic Assessment \\ (Penemuan Semula Nycticebus coucang insularis Robinson, 1917 (Primate: Lorisidae) di Pulau Tioman dan Penilaian Genetik Mitokondrianya)
}

\author{
JefFrine J. Rovie-Ryan*, Millawati Gani, Han Ming Gan, GilmoORE G. Bolongon, TAN ChEnG Cheng, \\ NORAZLINDA RAZAK, NORSYAMIMI ROSLI, MOHD AZIZOL AZIZ \& KALIP MATKASIM
}

\begin{abstract}
Slow lorises (Nycticebus) consist of eight species native to Southeast Asia while three species are recognised in Malaysia - N. coucang, N. menagensis and N. kayan. This study reports on the rediscovery of the subspecies N. coucang insularis Robinson, 1917 in Tioman Island and the genetic assessment of its mitochondrial DNA variation. Morphological measurements conform the specimen as the putative $\mathrm{N}$. coucang but with distinct colour and markings. Two mitochondrial DNA segments (cytochrome $\mathrm{b}$ and control region) were produced from the subspecies representing their first registered sequences in GenBank. Genetically, the subspecies showed $99 \%$ of nucleotide similarity to N. coucang species type for both the DNA segments and constitute its own unique haplotype. Phylogenetic trees constructed using three methods (neighbour joining, maximum likelihood and Bayesian inference) showed two major groups within Nycticebus; the basal group was formed by N. pygmaeus while the second group consisted of the remaining Nycticebus species. The phylogenetic position of the subspecies, however, remains unresolved due to the observed mixing between $\mathrm{N}$. coucang and N. bengalensis. Several reasons could lead to this condition including the lack of well documented voucher specimens and the short DNA fragments used. In addition, the possibility of hybridisation event between $\mathrm{N}$. coucang and $\mathrm{N}$. bengalensis could not be excluded as a possible explanation since both species occur sympatrically at the Isthmus of Kra region until the Thailand-Malaysia border. The rediscovery of this subspecies displays the unique faunal diversity that justifies the importance of Tioman Island as a protected area.
\end{abstract}

Keywords: mtDNA; Nycticebus coucang insularis; phylogenetic relationships; rediscovery; subspecies

\section{ABSTRAK}

Kongkang (Nycticebus) terdiri daripada lapan spesies yang berasal dari Asia Tenggara dengan tiga spesies dijumpai di Malaysia - N. coucang, N. menagensis dan N. kayan. Kajian ini melaporkan penemuan semula subspesies N. coucang insularis Robinson, 1917 di Pulau Tioman dan penilaian genetik DNA mitokondrianya. Ukuran morfologi yang diambil pada individu tersebut menunjukkan ia menyerupai spesies putatif $\mathrm{N}$. coucang namun terdapat perbezaan warna dan tanda pada badan. Dua segmen DNA mitokondria (sitokrom b dan rantau kawalan) dihasilkan daripada subspesies tersebut merupakan jujukan DNA pertama yang didaftarkan dalam GenBank. Secara genetik, subspesies ini menunjukkan 99\% persamaan nukleotida kepada jenis spesies N. coucang pada kedua-dua segmen DNA dan membentuk haplotip tersendiri. Pohon filogeni yang dibina menggunakan tiga kaedah (jiran sambung, kebolehjadian maksimum dan pentakbiran Bayesian) mendedahkan dua kumpulan utama dalam Nycticebus; kumpulan dasar dibentuk oleh N. pygmaeus manakala kumpulan kedua terdiri daripada spesies Nycticebus yang lain. Kedudukan filogenetik subspesies ini bagaimanapun masih tidak dapat diuraikan kerana pencampuran yang diperhatikan antara N. coucang dan N. bengalensis. Beberapa sebab boleh membawa kepada keadaan ini termasuk kekurangan dokumentasi baucer spesimen yang betul dan jujukan DNA pendek yang digunakan dalam analisis. Selain itu, kemungkinan kejadian hibridisasi antara N. coucang dan N. bengalensis tidak boleh dikecualikan sebagai penjelasan kerana kedua-dua spesies wujud secara simpatri dari kawasan Isthmus of Kra hingga sempadan Thailand-Malaysia. Penemuan semula subspesies ini memaparkan kepelbagaian fauna unik di Pulau Tioman yang menunjukkan kepentingannya sebagai kawasan perlindungan.

Kata kunci: Hubungan filogenetik; mtDNA; Nycticebus coucang insularis; penemuan semula; subspesies

\section{INTRODUCTION}

Slow lorises (Nycticebus spp.) are small nocturnal primates belonging to the family Lorisidae which has a wide distribution occupying 14 countries in the Southeast Asia (SEA) and adjacent areas (Nekaris \& Starr 2015). They are arboreal and can be found in various forest types including primary and secondary forests and even agricultural lands. Nycticebus species are heavily exploited in the wildlife trade and are popular as pets (Nekaris \& Jaffe 2007). In 2007, the Convention on International Trade in Endangered 
Species of Wild Fauna and Flora (CITES) elevated their status to Appendix I prohibiting all international trade of the species, their parts, or their derivatives (Nekaris \& Nijman 2007). In Peninsular Malaysia, under the new Wildlife Act 2010 [Act 716], all Nycticebus species are totally protected.

Currently, eight species within the genus are recognised; Nycticebus bancanus, $N$. bengalensis, $N$. borneanus, $N$. coucang, $N$. javanicus, N. kayan, $N$. menagensis and N.pygmaeus (Nekaris \& Starr 2015; Roos et al.2014). However, only five species have been assessed by the International Union for Conservation of Nature (IUCN) Red List of Threatened Species (Figure 1) while the remaining three species from Borneo (N.bancanus, $N$. kayan and $N$. borneanus) which were recently described remains not assessed. In Malaysia, at least three species of Nycticebus exist; $N$. coucang in the peninsula, while $N$. menagensis and N. kayan are found in Borneo. In Tioman Island, Robinson (1917) recognised a subspecies unique to the island and classified it as N.coucang insularis. Medway (1966) reported a specimen from the island in 1958 but since then no observations or collections were made on the subspecies which led to Lim et al. (1999) to speculate that the subspecies has gone extinct.

Recently, during the 2016 Biodiversity Inventory Programme held by the Department of Wildlife and National Parks (PERHILITAN) at Tioman Island, a Nycticebus individual was caught which could possibly represent one of the only two available specimens of the subspecies N. coucang insularis Robinson, 1917. Thus, this study documents the rediscovery of the subspecies and assess its mitochondrial genetic variation.

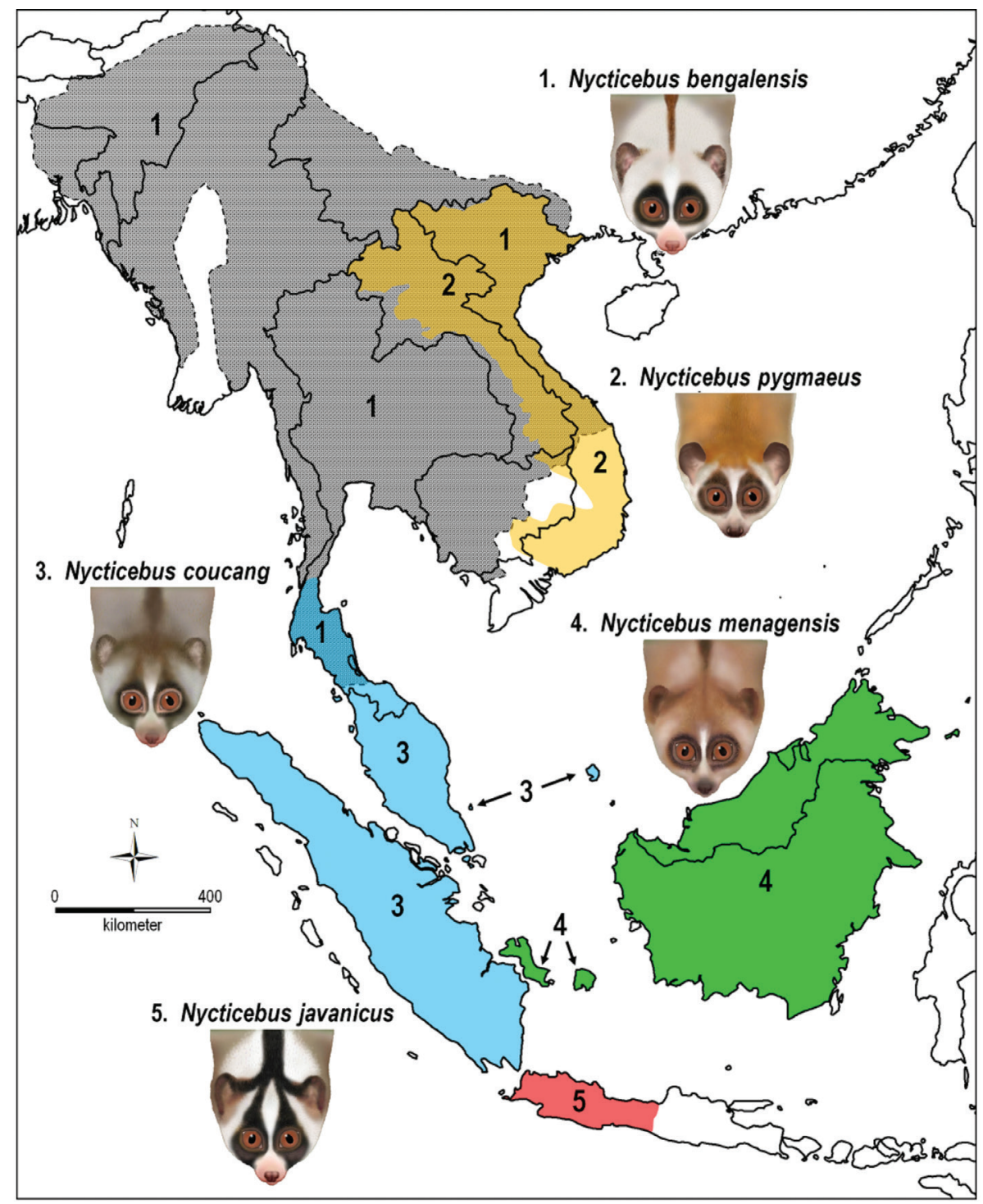

FIGURE 1. Distribution map of five Nycticebus species in Southeast Asia as assessed by IUCN (Nekaris \& Streicher 2008a, 2008b; Nekaris et al. 2013; Streicher et al. 2008a, 2008b). The remaining three recently recognised species (N. bancanus, $N$. kayan and $N$. borneanus) are found in Borneo. Note: $N$. bengalensis occurs sympatrically with $N$. pygmaeus and N. coucang. Illustration of Nycticebus were taken from Schulze \& Groves (2004) 


\section{MATERIALS AND METHODS}

\section{SAMPLE AND MORPHOMETRICS}

On $18^{\text {th }}$ April 2016, a male slow loris was caught at Kampung (Kpg.) Sungai Asah, Tioman Island using a scoop net at around $2000 \mathrm{~h}$ (Figure 2). Photographs and morphological measurements were taken according to the identification keys provided by Khan (1992) and Payne and Francis (2007) and buccal swabs were taken for DNA analysis. The animal was brought back alive and is currently housed at a captive facility maintained by the PERHILITAN.

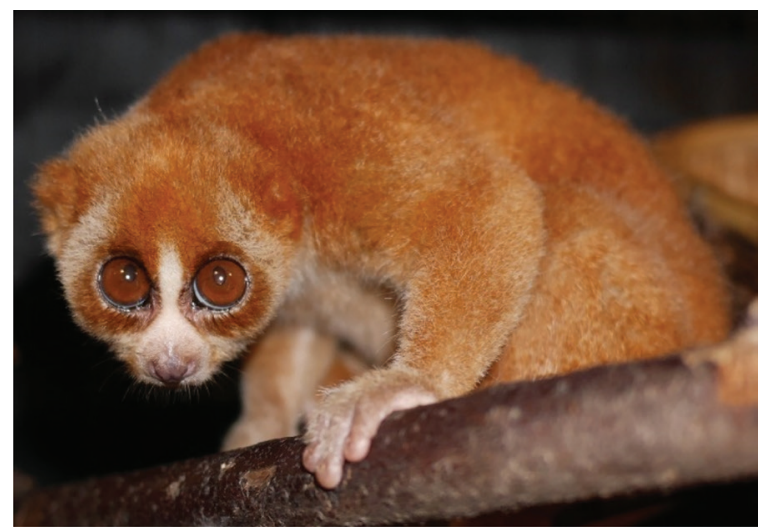

FIGURE 2. Nycticebus coucang insularis caught at Kpg. Sungai Asah, Tioman Island during the recent 2016 Biodiversity Inventory Programme. Photograph by Tan Cheng Cheng

\section{MOLECULAR ANALYSIS}

Genomic DNA extraction was conducted on the swab samples using the buccal swab protocol provided by the QIAamp® DNA Mini Kit (Qiagen, Germany). PCR amplifications were conducted on two mitochondrial DNA segments: the partial cytochrome $b$ gene (cyt $b$ ) using the universal primer pair of СҮТВ1/СҮТВ2 (Kocher et al. 1989); and the control region segment (CR) using the primer pair L15996/H16498 (Chen et al. 2006). Amplifications on both the mtDNA segments were conducted using the PCR mixtures described in Rovie-Ryan et al. (2014) and the thermal profiles as the following; initial denaturation at $95^{\circ} \mathrm{C}$ for $1 \mathrm{~min}$ and then 30 cycles each consisting of denaturation at $94^{\circ} \mathrm{C}$ for $1 \mathrm{~min}$, annealing at $50^{\circ} \mathrm{C}$ for $1 \mathrm{~min}$ and extending at $72^{\circ} \mathrm{C}$ for $1 \mathrm{~min}$, followed by a finally extension at $72^{\circ} \mathrm{C}$ for $3 \mathrm{~min}$. Cycle sequencing was carried out on the PCR products for both directions using the forward and reverse PCR primers on the ABI 3130xl DNA Analyzer (Applied Biosystems, USA) as provided by a service provider (1st Base Laboratories Sdn. Bhd., Selangor, Malaysia).

\section{SEQUENCE AND PHYLOGENETIC ANALYSES}

The DNA sequences obtained were examined using the software Geneious v5.6 (Drummond et al. 2012) and
BLAST analysis was conducted to check for sequence similarity (Altschul et al. 1990). The sequences obtained from the individual were registered with GenBank with the accession numbers KY680654 and KY680655 for cyt $b$ and CR segments, respectively. Other available sequences of Nycticebus from GenBank were downloaded for further analyses as listed in Appendix 1. Sequence characterisations including variable sites (VS), conserved sites (CS) and parsimony-informative sites (PIS) were done by using MEGA v7 (Kumar et al. 2016). Standard molecular diversity indices including number of haplotypes (NHap), haplotype diversity $(H d)$ (Nei 1987) and nucleotide diversity $(\pi)$ (Nei 1987) were calculated by using DnaSP v5 (Librado et al. 2009). In MEGA v7, genetic distances were calculated by using the Kimura two-parameter model (Kimura 1980).

To clarify the phylogenetic position of the subspecies within the genus Nycticebus, phylogenetic analyses were conducted on both the mtDNA segments separately using the neighbour-joining (NJ), maximum likelihood (ML) and the Bayesian inference (BI). The NJ and ML analyses were conducted in MEGA v7 with 2,000 bootstrap replicates (Felsenstein 1985). For both the mtDNA segments NJ analysis was performed by using the Kimura 2-Parameter distance model (Kimura 1980) with pairwise deletion option. For ML analysis, the trees were constructed using the Hasegawa-Kishino-Yano model (Hasegawa et al. 1985) and Tamura 3-parameter model (Tamura 1992) for the cyt $b$ and CR segment, respectively, as calculated in MEGA v7. BI was conducted by using the software BEAST v2.0 (Bouckaert et al. 2014). In BEAST v2.0, the following settings were enforced; four independent runs each with 50 million MCMC generations and sub-sampled every 50,000 generations, HKY85 substitution model with five gamma category counts (Hasegawa et al. 1985), Relaxed Clock Log Normal and Birth Death Model (Stadler 2010). Gray Slender Loris (Loris lydekkerianus), Red Slender Loris (Loris tardigradus) and West African Potto (Perodicticus potto) were used as the outgroup species in phylogenetic analyses following Somura et al. (2012) as these species are representatives from the major branches within the family Lorisidae.

\section{RESULTS AND DISCUSSION}

Morphological measurements taken on the individual (total length $=279 \mathrm{~mm}$, head body $=263 \mathrm{~mm}$, tail $=$ $16 \mathrm{~mm}$, ear $=18 \mathrm{~mm}$, hind foot $=45 \mathrm{~mm}$ and weight $=$ $500 \mathrm{~g}$ ) conform to the putative $N$. coucang with distinct colours and markings. Based on the facial colouration and markings, the individual showed close resemblance to one of the illustrations by Schulze and Groves (2004) whom described several types of variations occurring in $N$. coucang (Figure 3 ). This valuable specimen represent the only second available specimen of the subspecies $N$. coucang insularis after Medway (1966) caught the first type specimen from Kpg. Mukut, Tioman Island in 1958. Groves and Maryanto (2008) worked on the craniometrics 


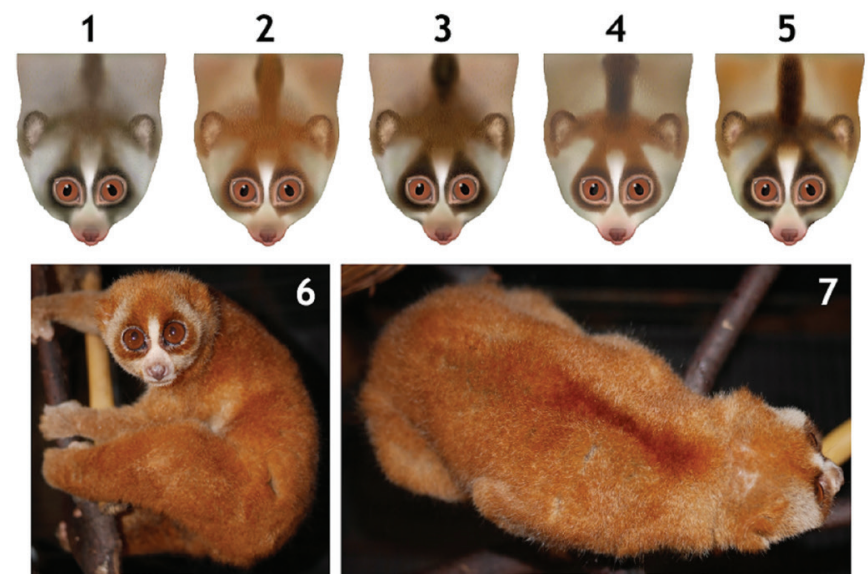

FIGURE 3. Colour and marking variation of $N$. coucang. 1-5 show variation of facial colourations and markings based on Schulze and Groves (2004). 6-7 (photographed by Cheng T.C.) represent the specimen caught at Tioman Island showing close resemblance to illustration 2

of the first type specimen and compared it to several Nycticebus skull specimens from the insular region of SEA and suggested that it belongs to the $N$. coucang type from Peninsular Malaysia and Sumatra although they noted that it falls at the edge of the range. Therefore, the rediscovery of this individual from Tioman Island marked an important finding after the gap of almost 60 years between the first and current specimens that can add more information and knowledge on the subspecies. Currently, the individual is kept at a captive facility maintained by the PERHILITAN and monitored for behaviour study.

DNA sequences with the length of 402 base pairs (bp) and 380 bp were obtained from the cyt $b$ and CR segments, respectively. Both the DNA sequences represent the first registered sequences of the subspecies in the GenBank database. BLAST result showed $99 \%$ of nucleotide similarity to the $N$. coucang species type for both the DNA sequences. Three transitional nucleotides were observed from both the mtDNA segments that distinguished the subspecies insularis from the other $N$. coucang forms (Table 1). Within $N$. coucang, eight haplotypes of $N$. coucang were observed for the cyt $b$ segment $(n=10)$ while six were observed for the CR segment $(n=7)$. For both segments, the subspecies insularis constituted its own unique haplotype. The sequence characteristics (CS, VS and PIS) and diversity indices (NHap, $H d$ and $\pi$ ) within Nycticebus are shown in Table 2. For both DNA segments, $N$. coucang demonstrated the highest nucleotide diversity $(\pi)$ compared to the other species. Table 3 summarises the genetic distances among the haplotypes of $N$. coucang for both the mtDNA segments. The insularis subspecies differed from the other $N$. coucang haplotypes by $0.8-8.3 \%$ for the cyt $b$ and $0.5-10.3 \%$ for the CR segment.

Phylogenetic trees constructed using the NJ, ML, and BI on cyt $b$ and CR segments produced contrasting topologies. The cyt $b$ segment produced a poorly resolved topology (data not shown) by which an admixture between the species $N$. bengalensis, $N$. coucang, $N$. javanicus and $N$. menagensis was observed, thus, it was not used for further discussion. The CR segment on the other hand provided a well resolved topology to clarify the relationships within the Nycticebus. The NJ, ML and BI trees based on CR segment had similar topologies, thus, the phylogeny was summarised using the NJ tree (Figure 4). In general, two major groups were observed. The basal group was formed by $N$. pygmaeus that diverged earlier from the other Nycticebus species, corresponding to previous studies (Chen et al. 2006, 2004; Somura et al. 2012). The second group consisted of the remaining Nycticebus species ( $N$. bengalensis, $N$. coucang, N.javanicus and N.menagensis) which were previously ranked at subspecies level within N. coucang.

Within the second group, N. javanicus and $N$. menagensis formed their own clades with strong support (>90\% of bootstrap values). However, mixing between $N$. bengalensis and N. coucang were observed. Specifically, a single sequence of $N$. coucang from GenBank (AY875955; Figure 4) was clustered within the $N$. bengalensis species group. Further investigation showed that all available $N$. coucang sequences from GenBank (AY875955 - AY875957, AY687887 - AY687888 and GQ449388) were obtained from either confiscated specimens or zoo animals thus raising doubt on the exact origin of the specimens. Therefore, due to the unknown exact locality of the specimens, we believe that the previous phylogenetic relationships constructed on Nycticebus (Chen et al. 2006, 2004) were erroneous, especially regarding the relationship between $N$. coucang and $N$. bengalensis. Evidently, this study points out the importance of using well documented voucher specimens or reference samples in phylogenetic studies.

In this study, we attempted to clarify the phylogenetic positioning of the subspecies $N$. c. insularis within Nycticebus. However, due to the mixing between $N$. coucang and $N$. bengalensis, the phylogenetic position of the subspecies however remains unresolved. Several reasons could lead to this condition including the doubtful 


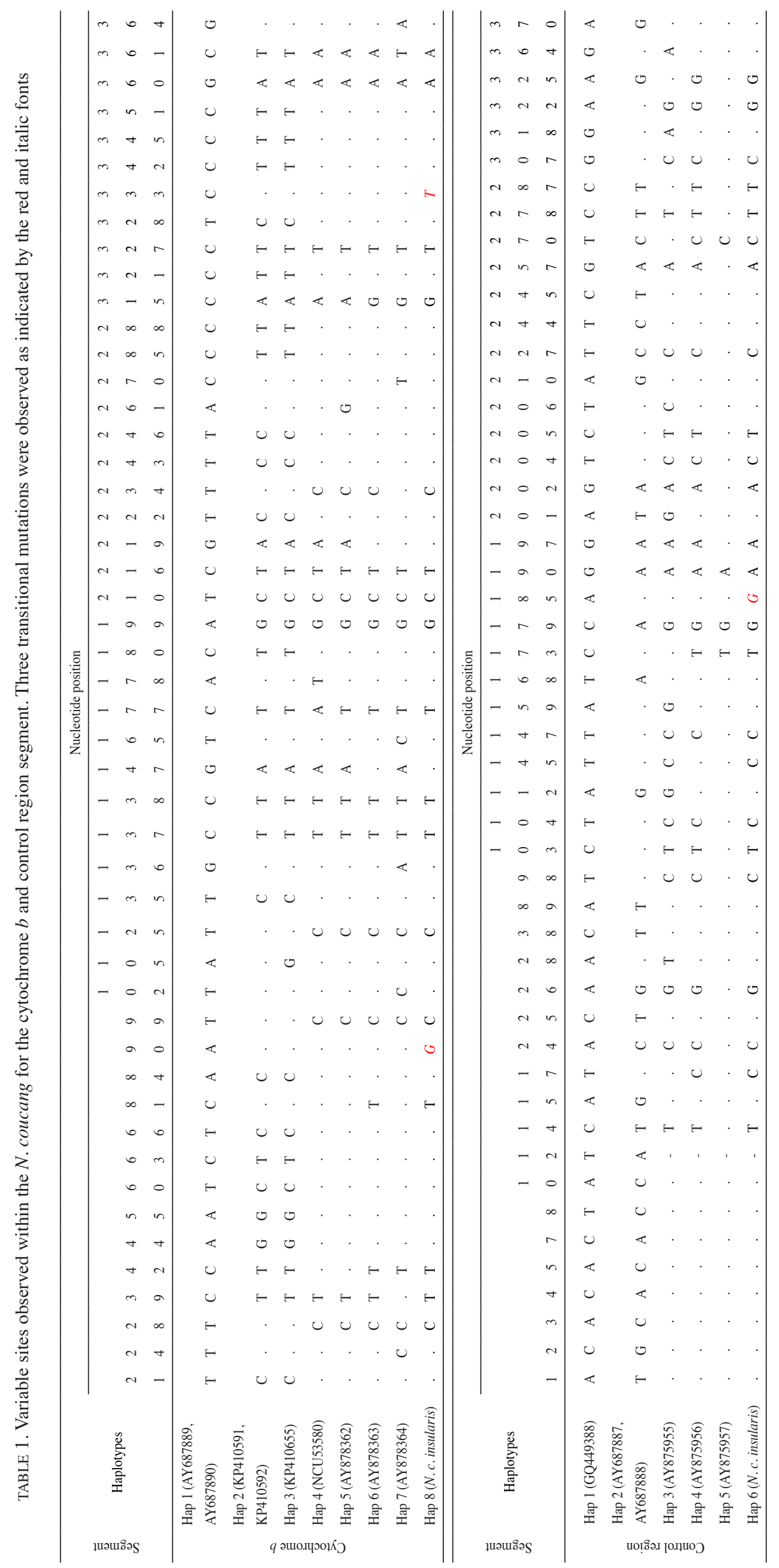


TABLE 2. Sequence characteristics (conserved sites, variable sites and parsimony informative sites) and diversity indices (number of haplotypes, haplotype diversity and nucleotide diversity) for Nycticebus species used in this study

\begin{tabular}{|c|c|c|c|c|c|c|c|c|c|c|c|c|c|c|}
\hline \multirow[b]{2}{*}{ Genus/ Species } & \multicolumn{7}{|c|}{ Cytochrome $b$} & \multicolumn{7}{|c|}{ Control region } \\
\hline & Z & $\tilde{U}$ & $\stackrel{s}{>}$ & $\tilde{\Omega}$ & 胥 & $\mathbb{Z}$ & b & Z & $\tilde{U}$ & $\stackrel{\infty}{>}$ & $\tilde{\Omega}$ & 疍 & $\mathbb{Z}$ & r \\
\hline Nycticebus bengalensis & 10 & 388 & 14 & 7 & 7 & 0.93 & 0.012 & 10 & 361 & 18 & 0 & 10 & 1.00 & 0.014 \\
\hline N. coucang & 10 & 353 & 49 & 38 & 8 & 0.96 & 0.050 & 7 & 333 & 50 & 42 & 6 & 0.95 & 0.062 \\
\hline N. javanicus & 5 & 370 & 32 & 0 & 3 & 0.70 & 0.032 & 2 & 377 & 4 & 0 & 2 & 1.00 & 0.011 \\
\hline N.menagensis & 4 & 389 & 13 & 0 & 3 & 0.83 & 0.016 & 6 & 372 & 9 & 3 & 4 & 0.80 & 0.010 \\
\hline N.pygmaeus & 17 & 391 & 11 & 3 & 8 & 0.73 & 0.005 & 23 & 368 & 14 & 2 & 13 & 0.88 & 0.005 \\
\hline Total Nycticebus & 46 & 314 & 88 & 77 & 25 & 0.95 & 0.076 & 48 & 297 & 86 & 70 & 34 & 0.97 & 0.064 \\
\hline
\end{tabular}

TABLE 3. Genetic distances calculated among the $N$. coucang haplotypes for the cytochrome $b$ (below the diagonal) and control region (above the diagonal, italics) segments of mtDNA

\begin{tabular}{|c|c|c|c|c|c|c|c|}
\hline Haplotype No. & Hap1 & Hap 2 & Hap 3 & Hap 4 & Hap 5 & Hap $6^{*}$ & Hap7 \\
\hline Hap1 & & 9.1 & 7.3 & 6.5 & 1.1 & 7.1 & \\
\hline Hap2 & 8.9 & & 10.3 & 8.5 & 8.8 & 9.1 & \\
\hline Hap3 & 9.2 & 0.2 & & 3.6 & 7.4 & 3.6 & \\
\hline Hap4 & 4.6 & 7.1 & 7.4 & & 5.3 & 0.5 & \\
\hline Hap5 & 4.7 & 6.9 & 7.2 & 0.8 & & 5.9 & \\
\hline Hap6 & 4.4 & 7.5 & 7.8 & 1.8 & 1.5 & & \\
\hline Hap7 & 5.5 & 8.4 & 8.6 & 3.6 & 3.3 & 2.8 & \\
\hline Hap8* & 4.9 & 8.0 & 8.3 & 2.3 & 2.0 & 0.5 & 3.3 \\
\hline
\end{tabular}

* subspecies insularis

origin of $N$. coucang specimens available from GenBank as described above. Additionally, the short DNA fragments used in this study hindered the discovery of more genetic variation (only two and one variable site observed in the cyt $b$ and $\mathrm{CR}$ segments, respectively) that could possibly distinguish the different species and subspecies. Nevertheless, the possibility of hybridisation event to occur between $N$. coucang and $N$. bengalensis could not be excluded as a possible explanation of the mixing of the species since both occur sympatrically at the Isthmus of Kra region until the Thailand-Malaysia border (see Figure 1). Therefore, to clarify this matter, efforts are underway to sequence individuals especially from $N$. coucang of known locality from Peninsular Malaysia.

In summary, the rediscovery of this subspecies marked a significant finding and further supports the unique faunal diversity of Tioman Island. This subspecies warrants a significant conservation status and should be managed and monitored as a separate management unit (Moritz 1994). This finding also contributed considerably to the diversity of Nycticebus in Malaysia generally which recently have seen at least three new species and possibly a new subspecies being discovered. Specifically, the accumulating discoveries of unique and endemic faunal species in Tioman Island (Chen \& Tan 2005; Lim et al. 1999; Onn et al. 2011; Yan et al. 2014; Yeo \& Ng 1999) justifies the importance of Tioman Island as a wildlife reserve. Management authorities should look into the possibility of establishing this protected area as a national park. Currently, further efforts are ongoing to measure the genetic diversity of this subspecies using complete mitochondrial genome.

\section{ACKNOWLEDGEMENTS}

The authors thank all the reviewers of this paper, Dr. Lim Boo Liat for the subspecies identification, Helga Schulze and Emeritus Prof. Colin Groves for permission to use the slow loris illustrations, the Director General and Director of the Ex-situ Conservation Division of PERHILITAN for permission to conduct this research; and all personnel involved during the 2016 Biodiversity Inventory Programme. The inventory programme was funded under the National Biodiversity Data Collection, Data Management and Data Dispersal Programme of the $11^{\text {th }}$ Malaysia Plan. 


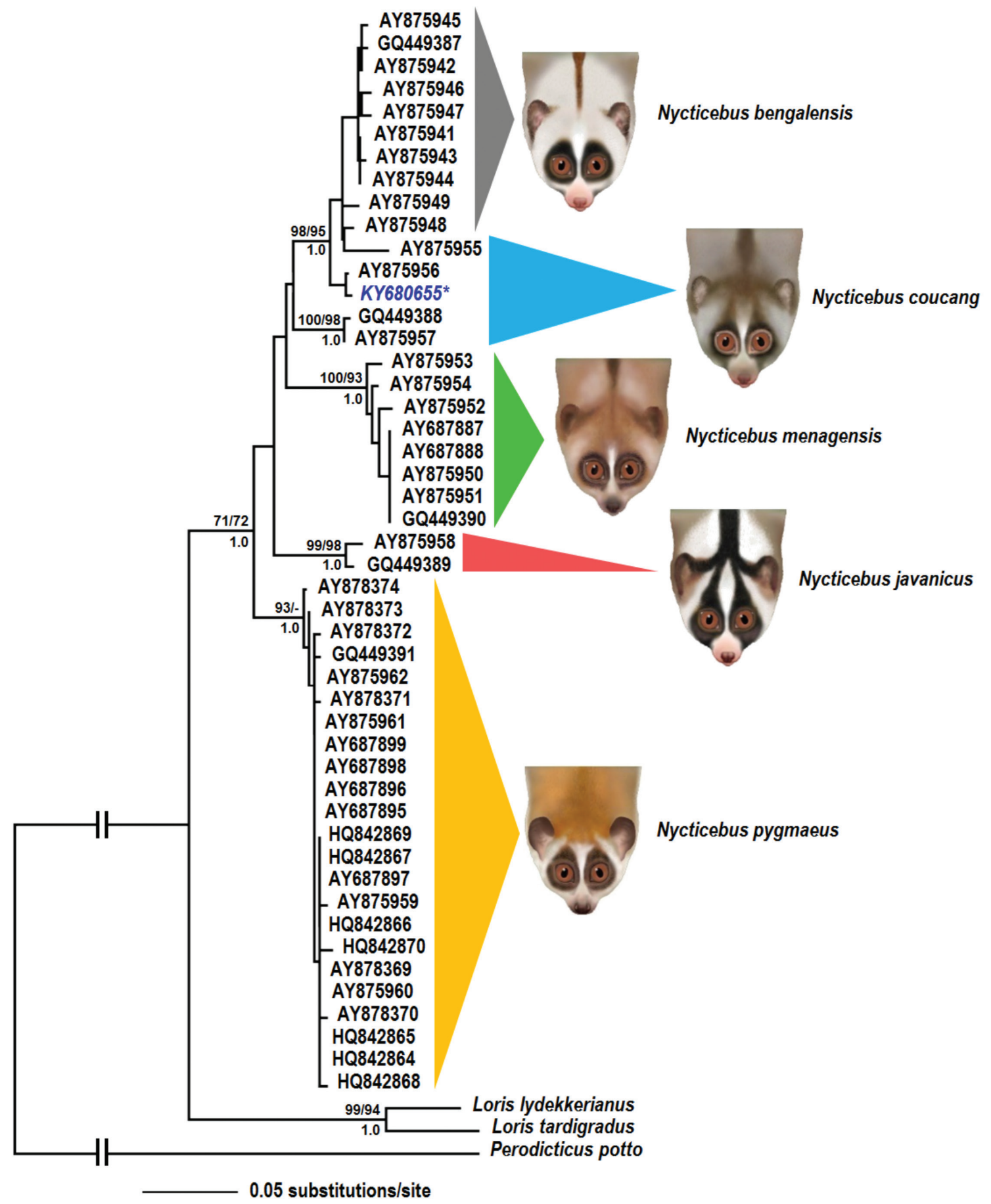

FIGURE 4. Phylogenetic relationships (NJ tree) of the Nycticebus species constructed using the control region segment. Values above the branches represent the bootstrap estimates for NJ and ML, respectively (only values above $50 \%$ are shown).

Values below the branches represent BI posterior probability

\section{REFERENCES}

Altschul, S.F., Gish, W., Miller, W., Myers, E.W. \& Lipman, D.J. 1990. Basic local alignment search tool. Journal of Molecular Biology 215(3): 403-410.

Bouckaert, R., Heled, J., Kühnert, D., Vaughan, T.G., Wu, C.H., Xie, D., Suchard, M.A., Rambaut, A. \& Drummond, A.J. 2014. BEAST2: A software platform for bayesian evolutionary analysis. PLoS Computational Biology 10(4): e1003537.
Chen, I.S. \& Tan, H.H. 2005. A new species of freshwater goby (Teleostei: Gobiidae: Stiphodon) from Pulau Tioman, Pahang, Peninsular Malaysia. Raffles Bulletin of Zoology 53(2): 81-86.

Chen, J.H., Crow, P., Narushima, E., Zhang, H.W. \& Zhang, Y.P. 2004. Molecular phylogeny of Slow Lorises (Nycticebus) revealed by D-loop sequences and complete cytochrome $b$ gene sequences of mitochondrial DNA.Zoological Research 25(4): 292-297.

Chen, J.H., Pan, D., Groves, C., Wang, Y.X., Narushima, E., Fitch-Snyder, H., Crow, P., Thanh, V.N., Ryder, O., Zhang, 
H.W., Fu, Y.X. \& Zhang, Y.P. 2006. Molecular phylogeny of Nycticebus inferred from mitochondrial genes. International Journal of Primatology 27(4): 1187-1200.

Drummond, A.J., Ashton, B., Buxton, S., Cheung, M., Cooper, A., Duran, C., Field, M., Heled, J., Kearse, M., Markowitz, S., Moir, R., Stones-Havas, S., Sturrock, S., Thierer, T. \& Wilson, A. 2012. Geneious version 5.6.7. http://www.geneious.com.

Felsenstein, J. 1985. Confidence limits on phylogenies: An approach using the bootstrap. Evolution 39(4): 783-791.

Groves, C. \& Maryanto, I. 2008. Craniometry of slow lorises (genus Nycticebus) of insular Southeast Asia. In Primates of the Oriental Night, edited Shekelle, M., Maryanto, I. \& Groves, I. Indonesia: LIPI Press. pp. 115-122.

Hasegawa, M., Kishino, H. \& Yano, T. 1985. Dating of the humanape splitting by a molecular clock of mitochondrial DNA. Journal of Molecular Evolution 22(2): 160-174.

Khan, M.M. 1992. Mamalia Semenanjung Malaysia. Kuala Lumpur, Malaysia: Department of Wildlife and Parks.

Kimura, M. 1980. A simple method for estimating evolutionary rate of base substitutions through comparative studies of nucleotide sequences. Journal of Molecular Evolution 16(2): 111-120

Kocher, T.D., Thomas, W.K., Meyer, A., Edwards, S.V., Pääbo, S., Villablanca, F.X. \& Wilson, A.C. 1989. Dynamics of mitochondrial DNA evolution in animals: Amplification and sequencing with conserved primers. Proceedings of the National Academy of Sciences of the United States of America 86(16): 6196-6200.

Kumar, S., Stecher, G. \& Tamura, K. 2016. MEGA7: Molecular evolutionary genetics analysis version 7.0 for bigger datasets. Molecular Biology and Evolution 33(7): 1870-1874.

Librado, P. \& Rozas, J. 2009. DnaSP v5: A software for comprehensive analysis of DNA polymorphism data. Bioinformatics 25(11): 1451-1452.

Lim, B.L., Lim, K.K.P. \& Yong, H.S. 1999. The terrestrial mammals of Pulau Tioman, Peninsular Malaysia, with a catalogue of specimens at the Raffles Museum, National University of Singapore. Raffles Bulletin of Zoology Supplement No. 6: 101-123.

Medway, L. 1966. Observations of the fauna of Pulau Tioman and Pulau Tulai. 2. The mammals. Bulletin of the Natural Museum, Singapore 34: 9-32.

Moritz, C. 1994. Defining 'evolutionary significant units' for conservation. Tree 9(10): 373-375.

Nei, M. 1987. Molecular Evolutionary Genetics. New York: Columbia University Press.

Nekaris, K.A.I. \& Starr, C.R. 2015. Conservation and ecology of the neglected slow loris: Priorities and prospects. Endangered Species Research 28(1): 87-95.

Nekaris, K.A.I. \& Jaffe, S. 2007. Unexpected diversity of slow lorises (Nycticebus spp.) within the Javan pet trade implications for slow loris taxonomy. Contributions to Zoology 76(3): 187-196.

Nekaris, K.A.I. \& Nijman, V. 2007. CITES proposal highlights rarity of Asian nocturnal primates (Lorisidae: Nycticebus). Folia Primatologica 78: 211-214.

Onn, C.K., Grismer, L.L. \& Grismer, J. 2011. A new insular, endemic frog of the genus Kalophrynus Tschudi, 1838 (Anura: Microhylidae) from Tioman Island, Pahang, Peninsular Malaysia. Zootaxa 3123: 60-68.

Payne, J. \& Francis, C. 2007. A Field Guide to the Mammals of Borneo. Sabah, Malaysia: The Sabah Society.
Robinson, H.C. 1917. On three new races of Malayan mammals. Journal of the Federated Malay States Museums 7(3): 101105.

Roos, C., Boonratana, R., Supriatna, J., Fellowes, J.R., Groves, C.P., Nash, S.D., Rylands, A.B.\& Mittermeier, R.A. 2014.An updated taxonomy and conservation status review of Asian primates. Asian Primates Journal 4(1): 2-38.

Rovie-Ryan, J.J., Abdullah, M.T., Sitam, F.T., Tan, S.G., Basir, M.M., Abidin, Z.Z., Keliang, C. \& Denel, A. 2014. Mitochondrial DNA diversity of the long-tailed macaque (Macaca fascicularis) from the northern region of Peninsular Malaysia. Journal of Wildlife and Parks 29: 1-8.

Schulze, H. \& Groves, C. 2004. Asian lorises: Taxonomic problems caused by illegal trade. In Conservation of Primates in Vietnam (Proceedings of the International Symposiumat Cuc Phuong National Park, 18. - 20. November 2003), edited by Nadler, T., Streicher, U. \& Long, H.T. Hanoi: Haki Publishing. pp. 33-36.

Somura, H., Hori, H. \& Manome, Y. 2012. Sequence analysis of mitochondrial DNAs of 12S rRNA, 16S rRNA, and cytochrome oxidase subunit 1 (COI) regions in slow lorises (genus Nycticebus) may contribute to improved identification of confiscated specimens. ISRN Zoology 2012: 498731.

Stadler, T. 2010. Sampling through time in birth-death trees. Journal of Theoretical Biology 267(3): 396-404.

Tamura, K. 1992. Estimation of the number of nucleotide substitutions when there are strong transition-transversion and G + C-content biases. Molecular Biology and Evolution 9: 678-687.

Yan, J., Tian, C., Zhou, J., Bauer, A.M., Lee Grismer, L. \& Zhou, K. 2014. Complete mitochondrial genome of the Tioman Island rock gecko, Cnemaspis limi (Sauria, Gekkota, Gekkonidae). Mitochondrial DNA 25(3): 181-182.

Yeo, D.C.J. \& Ng, P.K.L. 1999. A new species of Geosesarma (Crustacea: Decapoda: Brachyura: Grapsidae) from Pulau Tioman, Peninsular Malaysia. The Raffles Bulletin of Zoology Supplement No. 6: 189-196.

Jeffrine J. Rovie-Ryan*, Millawati Gani \& Norsyamimi Rosli National Wildlife Forensic Laboratory (NWFL)

Ex-Situ Conservation Division

Department of Wildlife and National Parks (PERHILITAN)

KM 10 Jalan Cheras

56100 Kuala Lumpur, Federal Territory

Malaysia

Jeffrine J. Rovie-Ryan* \& Norsyamimi Rosli

Institute of Tropical Biodiversity and Sustainable Development Universiti Malaysia Terengganu

21030 Kuala Nerus, Terengganu Darul Iman

Malaysia

Han Ming Gan

School of Life \& Environmental Sciences

Faculty of Science, Engineering and Built Environment

Deakin University, Locked Bag 20001

Geelong, Victoria 3220

Australia

Han Ming Gan

Genomic Facility, School of Science

Monash University Malaysia 
Jalan Lagoon Selatan, Bandar Sunway

47500 Subang Jaya, Selangor Darul Ehsan

Malaysia

Gilmoore G. Bolongon, Tan Cheng Cheng, Norazlinda Razak \& Mohd Azizol Aziz

Biodiversity Conservation Division

Department of Wildlife and National Parks (PERHILITAN)

KM 10 Jalan Cheras

56100 Kuala Lumpur, Federal Territory

Malaysia
Kalip Matkasim

Institute of Biodiversity

Department of Wildlife and National Parks (PERHILITAN)

Bukit Rengit 28500 Lanchang, Pahang Darul Makmur

Malaysia

*Corresponding author; email: jeffrine@wildlife.gov.my

Received: 19 August 2017

Accepted: 21 June 2018 
APPENDIX 1. List of GenBank sequences used in this study

\begin{tabular}{|c|c|c|c|}
\hline \multirow[t]{2}{*}{ No. } & \multirow[t]{2}{*}{ Genus/ Species } & \multicolumn{2}{|c|}{ GenBank Acc No. } \\
\hline & & Cyt $b$ & $\mathrm{CR}$ \\
\hline 1. & Nycticebus bengalensis & $\begin{array}{l}\text { AY441477 } \\
\text { AY878360 } \\
\text { KP410608 } \\
\text { KP410618 } \\
\text { KP410627 } \\
\text { KP410638 } \\
\text { KP410649 } \\
\text { KP410652 } \\
\text { KP410662 } \\
\text { KP410666 }\end{array}$ & $\begin{array}{l}\text { AY875941 } \\
\text { AY875942 } \\
\text { AY875943 } \\
\text { AY875944 } \\
\text { AY875945 } \\
\text { AY875946 } \\
\text { AY875947 } \\
\text { AY875948 } \\
\text { AY875949 } \\
\text { GQ449387 }\end{array}$ \\
\hline 2. & N. coucang & $\begin{array}{l}\text { AY687889 Hap1 } \\
\text { AY687890 Hap1 } \\
\text { KP410591 Hap1 } \\
\text { KP410592 Hap1 } \\
\text { KP410655 Hap1 } \\
\text { NCU53580 Hap1 } \\
\text { AY878362 Hap1 } \\
\text { AY878363 Hap1 } \\
\text { AY878364 Hap1 }\end{array}$ & $\begin{array}{l}\text { AY687887 } 7_{\text {Hap1 }} \\
\text { AY687888 Hap1 } \\
\text { GQ449388 Нар2 } \\
\text { AY875955 Hap3 } \\
\text { AY875956 } 6^{\text {Hap4 }} \\
\text { AY875957 Hap5 }\end{array}$ \\
\hline 3. & N. javanicus & $\begin{array}{l}\text { AY878365 } \\
\text { KP410601 } \\
\text { KP410612 } \\
\text { KP410654 } \\
\text { KP410658 }\end{array}$ & $\begin{array}{l}\text { AY875958 } \\
\text { GQ449389 }\end{array}$ \\
\hline 4. & N. menagensis & $\begin{array}{l}\text { AY878361 } \\
\text { KP410604 } \\
\text { KP410617 } \\
\text { KP410632 }\end{array}$ & $\begin{array}{l}\text { AY875950 } \\
\text { AY875951 } \\
\text { AY875952 } \\
\text { AY875953 } \\
\text { AY875954 } \\
\text { GQ449390 }\end{array}$ \\
\hline 5. & N.pygmaeus & $\begin{array}{l}\text { AY441476 } \\
\text { AY687891 } \\
\text { AY687892 } \\
\text { AY687893 } \\
\text { AY687894 } \\
\text { AY687900 } \\
\text { AY878366 } \\
\text { AY878367 } \\
\text { AY878368 } \\
\text { KP410590 } \\
\text { KP410606 } \\
\text { KP410607 } \\
\text { KP410614 } \\
\text { KP410624 } \\
\text { KP410626 } \\
\text { KP410648 } \\
\text { KP410664 }\end{array}$ & $\begin{array}{l}\text { AY687895 } \\
\text { AY687896 } \\
\text { AY687897 } \\
\text { AY687898 } \\
\text { AY687899 } \\
\text { AY875959 } \\
\text { AY875960 } \\
\text { AY875961 } \\
\text { AY875962 } \\
\text { AY878369 } \\
\text { AY878370 } \\
\text { AY878371 } \\
\text { AY878372 } \\
\text { AY878373 } \\
\text { AY878374 } \\
\text { GQ449391 } \\
\text { HQ842864 } \\
\text { HQ842865 } \\
\text { HQ842866 } \\
\text { HQ842867 } \\
\text { HQ842868 } \\
\text { HQ842869 } \\
\text { HQ842870 }\end{array}$ \\
\hline 6. & Loris lydekkerianus & KC757402 & KC757402 \\
\hline 7. & L. tardigradus & AB371094 & AB371094 \\
\hline 8. & Perodicticus potto & AB371095 & AB371095 \\
\hline
\end{tabular}

